ISSN : 2354 - 6034 (Print)

ISSN : 2599 - 0187 (Online)

\title{
PENGARUH PEMILU PRESIDEN INDONESIA TAHUN 2019 TERHADAP ABNORMAL RETURN DAN TRADING VOLUME ACTIVITY STUDI PADA SAHAM LQ45
}

\author{
Nurul Saadah Ivani \\ Magister Ekonomi Syariah \\ Universitas Islam Negeri Sunan Kalijaga Yogyakarta \\ Email: nurulivani73@gmail.com
}

\begin{abstract}
Abstrak
Penelitian ini menggunakan metode analisis studi peristiwa (event study). Periode penelitian yang digunakan adalah 10 hari bursa, meliputi 5 hari sebelum dan 5 hari sesudah peristiwa pemilu presiden indonesia tahun 2019. Uji statistik yang digunakan untuk menguji hipotesis adalah Uji One Sample t-test dan Uji beda Paired Sample t-test. Hasil uji One Sample t-testmenunjukkan bahwa terdapat abnormal return bernilai negatif sebelum dan sesudah pemilu di sekitar tanggal peristiwa, yang berarti bahwa pasar bereaksi terhadap peristiwa tersebut. Sedangkan hasil uji beda Paired Sample t-testmenunjukkan bahwa tidak terdapat perbedaan yang signifikan antara Average Abnormal Return (AAR) sebelum dan sesudah peristiwa pemilu presiden Indonesia. Hasil uji beda Paired Sample ttestjugamenunjukkan bahwa tidak terdapat perbedaan yang signifikan antara Average Trading Volume Activity(ATVA) pada periode sebelum dan sesudah pemilu presiden Indoenesia 2019.
\end{abstract}

Kata Kunci: Studi Peristiwa, Abnormal Return, Trading Volume Activity, Pemilu Presiden.

\section{LATAR BELAKANG}

Investasi adalah salah satu kegiatan yang sangat diminati saat ini, investasi merupakan penempatan sejumlah dana pada saat ini dengan harapan untuk memperoleh keuntungan dimasa yang akan datang, ${ }^{1}$ disamping pengetahuannya tentang investasi, manfaat dari investasi adalah hal yang ingin sekali dicapai oleh para investor berupa dividen dan gain. Salah satu komponen investasi adalah saham. Saham merupakan tanda kepemilikan dari investasi yang dimiliki oleh investor yang berasal dari perusahaan yang gopublic atau perusahaan yang terdaftar di pasar saham. Gopublic merupakan penawaran saham atau obligasi kepada masyarakat oleh pihak emiten/perusahaan yang melakukan penjualan efek di pasar modal.

\footnotetext{
${ }^{1}$ Abdul Halim, 2005, “Analisis Investasi”, Salemba Empat, Jakarta, hal.4.
} 
Aktivitas pasar modal adalah salah satu potensi perekonomian nasional, karena memiliki peranan penting dalam perkembangan perekonomian suatu negara. Dukungan sektor swasta menjadi kekuatan bagi negara dalam hal pembangunan dan pengembangan aktivitas perekonomian. Pasar modal Indonesia masih didominasi oleh para investor asing, idealnya dalam sebuah pasar modal perlu ada keseimbangan antara pemodal lokal dengan pemodal asing.

Perkembangan pasar modal di Indonesia mengalami perkembangan yang sangat pesat terutama setelah adanya berbagai regulasi dari pemerintah di bidang keuangan dan perbankan termasuk pasar modal. Perkembangan pasar modal di Indonesia di tandai dengan adanya pasar modal syariah yang bertujuan untuk membantu para investor yang ingin menginvestasikan dananya secara syariah dan juga semakin meningkatnya minat msyarakat dalam berinvestasi.

Peningkatan kesadaran masyarakat dalam mengenai pentingnya berinvestasi adalah hal yang baik karena dana yang digunakan dalam berinvesatsi dapat membantu mendorong perekonomian di Indonesia. Jumlah penduduk Indonesia yang sangat banyak dapat dan peningkatan sumber daya manusia yang baik serta sosialisasi mengenai pentingnya investasi dan peranan pasar modal, hal ini akan berdampak pada pengetahuan masyarakat terhadap produk-produk di pasar modal. Sehingga pasar modal Indonesia akan tahan dalam mengahadapi guncangan ekonomi dari luar.

Dalam melakukan aktivitas investasi diperlukan strategi yang baik dalam memilih jenis investasi dan stategi apa yang tepat untuk digunakan agar dapat memperkecil resiko kerugian investasi. Perencanaan stategi investasi dapat dipengaruhi oleh isu-isu yang beredar di masyarakat peristiwa maupun informasi yang diumumkan oleh pemerintah. Informasi yang diperoleh tersebut akan mempengaruhi para investor dalam memahami dan meramalkan kondisi ekonomi makro di masa mendatang yang akan sangat berguna dalam pengambilan keputusan investasi yang menguntungkan.

Pasar modal akan mencerminkan apa yang tejadi pada perekonomian makro karena nilai dan aktivitas investasi ditentukan oleh aliran kas yang diharapkan serta tingkat return yang disyaratkan atas investasi tersebut dan faktor tersebut dipengaruhi oleh perubahan lingkungan makro ${ }^{2}$.Salah satu peristiwa yang berdampak secara makro dalam perekonomian adalah pemilihan presiden, meskipun pemilu presiden merupakan aktiviats politik namun, memiliki pengaruh yang besar dalam menjaga kestabilan negara. Persitiwa pemilu April 2019 diharapkan selalu membawa perubahan yang lebih baik dari pemilu sebelumnya. Terkait tujuan kemajuan perekonomian, apabila stabilitas politik dan ekonomi sangat baik, maka akan berdampak baik terhadap repons investor karena mereka merasa aman menanamkan modalnya di pasar modal. Namun apabila stabilitas ekonomi dan politik kurang baik maka para investor akan ragu untuk menanamkan modalnya dipasar modal.

Indonesia akan melakukan pemilihan prsiden pada 17 April 2019 dimana pemilihan presiden ini adalah salah satu peristiwa politik yang berdampak secara

${ }^{2}$ EduardusTandelilin. 2010. Portofolio dan Investasi, edisi 1, Yogyakarta: Kanisius, Hal 339. 
makroterhadap perekonomian suatu negara, meskipun pemilu presiden merupakan peristiwa nonekonomi namun, memiliki pengaruh yang besar terhadap arah kebijakan karena akan memberikan gambaran atau arah perekonomian dimasa mendatang. Kenapa pemilu ini menjadi sangat penting terkait berubahnya harga saham dan arah investasi para investor? Karena, para investor tentu hanya akan berinvestasi pada saham-saham yang memiliki return yang tinggi dan memiliki prospek yang bagus dimasa depan. Sehingga, mereka akan cenderung menjual atau membeli saham yang diprediksi akan sangat menguntungkan bagi mereka dengan mempertimbangkan berbagai informasi dan peristiwa yang ada.

Penelitian ini dilakukan dengan menguji pengaruh pemilu presiden Indonesia tahun 2019 terhadap abnormal return dan tranding volume activity setelah peristiwa pemilihan umum presiden 2019 dan sesudahnya terhadap sahamsaham yang terdaftar di LQ45. Alasan dalam pemilihan saham LQ45 sebagai objek penelitian karena Indeks LQ45 merupakan indeks saham unggulan di bursa efek Indoensia yang mempertimbangkan faktor likuiditas, kapitalisasi pasar, kinerja fundamental yang baik ${ }^{3}$ dengan jumlah sampel yang besar diharapkan dapat menginterpretasikan kondisi pasar modal di Indonesia. Berdasarkan uraian di atas maka judul penelitian ini mengenai "Pengaruh Pemilu Presiden Indonesia tahun 2019terhadap Abnormal Return dan Trading Volume Activity Studi pada Saham LQ45”.

\section{RUMUSAN MASALAH}

1. Apakah terdapat abnormal return yang signifikan setelah pemilu presiden Indonesia tahun 2019?

2. Apakah terdapat trading volume activity yang signifikan setelah pemilu presiden Indonesia tahun 2019?

3. Apakah terdapat perbedaan rata-rata abnormal returnsebelum dan setelah pemilu presiden Indonesia tahun 2019?

4. Apakah terdapat perbedaan rata-rata trading volume activity sebelum dan setelah pemilu presiden Indonesia tahun 2019?

\section{KAJIAN PUSTAKA}

\section{Pasar Modal}

Pasar modal adalah pertemuan antara pihak yang memiliki kelebihan dana dengan memperjual-belikan sekuritas ${ }^{4}$. Pada pasar modal ada berbagai instrumen keuangan jangka panjang yang bisa diperjual-belikan baik itu yang diterbitkan oleh pemerintah maupun swasta.

\section{Efisiensi Pasar Modal}

${ }^{3}$ JogiyantoHartono. 2010. Teori Portofolio dan Analisis Investasi dan Instrumen Keuangan Pasar Modal. cetakan ke-7. Jogjakarta:BPFE, Hal 108 13.

${ }^{4}$ EduardusTandelilin. 2010. Portofolio dan Investasi, edisi 1, Yogyakarta: Kanisius, Hal 
Pasar modal yang efisien adalah kondisi dimana harga saham di pasar modal dapat merespon isu-isu yang beredar baik isu positif atau isu negatif. Pasar dapat dikatakan efisien jika mencerminkan keadaan yang sebenarnya artinya bahwa harga yang tercermin sesuai dengan informasi yang ada. Meskipun proses penyesuaian harga tidak selalu berjalan sempurna tetapi yang terpenting adalah harga yang terbentuk tidak memiliki bias.

\section{Saham}

Saham merupakan surat berharga yang dapat diperjualbelikan sebagai tanda penyertaan atau kepemilikan individu maupun institusi dalam suatu perusahaan $^{5}$.

\section{Aktivitas Volume Perdagangan (Trading Volume Activity)}

Trading Volume Activity adalah penjualan dari setiap transaksi yang terjadi di bursa saham pada swaktu dan saat tertentu dan merupakan salah satu faktor yang juga memberikan pengaruh terhadap pergerakan harga saham. Volume perdagangan saham merupakan besarnya jumlah lembar saham yang diperdagangkan pada waktu tertentu. Semakin besar volume perdagangan suatu saham menunnjukkan bahwa, saham tersebut aktif dan sering ditransaksikan di pasar modal.

Aktivitas volume perdagangan juga menjadi unsur penting dalam melakukan prediksi sebagai bagian dari onformasi yang memberikan signal pergerakan harga berikutnya dimana harga saham pershare tidak dapat disampaikan kepada pelaku pasar (Mahajan dan Singh, 2008). Foster (1986) dalam Sri dkk menyatakan bahwa volume perdagangan dapat dilihat dengan menggunakan indikator aktivitas perdagangan (Trading Volume Activity / TVA) dengan rumus sebagai berikut:

$$
\text { TVA }=\frac{\sum \text { saham i ditransaksikan pada waktu t }}{\sum \text { saham } \mathrm{i} \text { beredar waktu } \mathrm{t}}
$$

\section{Event Study}

Event study merupakan studi yang mempelajari reaksi pasar terhadap suatu peristiwa (event) yang informasinya dipublikasikan sebagai suatu pengumuman. Reaksi pasar dalam hal ini adalah abnormal return dan trading volume activity. Studi peristiwa dapat digunakan untuk menguji kandungan informasi dari suatu

${ }^{5}$ NorHadi. 2013. Pasar Modal: Acuan Teoritis dan Praktis Investasi dan Instrumen Keuangan Pasar Modal. Edisi Pertama, Yogyakarta: Graha Ilmu, Hal 67 
pengumuman yang dapat digunakan untuk mengukur tingkat efisiensi pasar bentuk stengah kuat ${ }^{6}$

\section{Return}

Return dapat diartikan sebagai hasil pengembalian yang diperoleh investor dari kegiatan investasi yang dilakukan. Return juga merupakan imbalan ataskeberanian investor dalam menanggung resiko atas investasi yang dilakukan ${ }^{7}$.

\section{Realized Return (Return Sesungguhnya)}

Realized Return adalah return yang terjadi bukan return yang diharapkan. Realized return dihitung menggunakan data histori yang digunakan sebagai salah satu pengukur dari kinerja perusahaan selain itu juga dapat menjadi dasar penentuan expected return dan risiko dimasa datang.

$$
\begin{aligned}
& \text { Realized return }=\frac{\mathrm{P}_{\mathrm{t}}-\mathrm{P}_{\mathrm{t}-1}}{\mathrm{P}_{\mathrm{t}-1}} \\
& \mathrm{Pt}-1: \text { Harga saham penutupan hari sebelumnya } \\
& \mathrm{Pt} \quad: \text { Harga saham penutupan hari ini }
\end{aligned}
$$

\section{Return Harapan (Expected Return)}

Return ekspektasi merupakan return yang diharapkan oleh investor. Perhitungan return ekpektasi untuk penelitian event study dapat menggunakan market-adjusted model. Market adjusted model adalah cara penghitungan expected return dengan menganggap bahwa penduga yang terbaik untuk memperkirakan return suatu sekuritas adalah menggunakan return indeks pasar pada saat tersebut.

\section{Return Tidak Normal (Abnormal Return)}

Abnormal return adalah selisih antara return sesungguhnya dengan return ekpektasi ${ }^{8}$. Pasar akan memberikan respon untuk berita baik dengan abnormal return yang bernilai positif dan respon abnormal return negatif untuk berita buruk. Abnormal return ini biasanya digunakan untuk menguji kandungan informasi dari suatu peristiwa.

$$
\mathrm{RTN}_{\mathrm{it}}=\mathrm{R}_{\mathrm{it}}-\mathrm{E}\left(\mathrm{R}_{\mathrm{it}}\right)
$$

${ }^{6}$ JogiyantoHartono. 2010. Teori Portofolio dan Analisis Investasi dan Instrumen Keuangan Pasar Modal. cetakan ke-7. Jogjakarta:BPFE, Hal 50

${ }^{7}$ EduardusTandelilin. 2010. Portofolio dan Investasi, edisi 1, Yogyakarta: Kanisius, Hal 147.

${ }^{8}$ JogiyantoHartono. 2010. Teori Portofolio dan Analisis Investasi dan Instrumen Keuangan Pasar Modal. cetakan ke-7. Jogjakarta:BPFE, Hal 579 
$\mathrm{RTN}_{\mathrm{it}}$ : abnormal return sekuritas ke-i pada peristiwa ke-t

$\mathrm{R}_{\mathrm{it}} \quad$ : return sesungguhnya untuk sekuritas ke-i pada peristiwa ke-t

$\mathrm{R}_{\mathrm{it}} \quad$ : return sesungguhnya untuk sekuritas ke-i pada peristiwa ke- $\mathrm{t}$

$\mathrm{E}\left(\mathrm{R}_{\mathrm{it}}\right)$ : return ekspektasi sekuritas ke-i untuk periode peristiwa ke-t

\section{Hipotesis}

$\mathrm{H}_{1}$ : terdapat abnormal return yang signifikan setelah pemilu presiden Indonesia tahun 2019

$\mathrm{H}_{2}$ : terdapat trading volume activity yang signifikan setelah pemilu presiden Indoensia tahun 2019

$\mathrm{H}_{3}$ : terdapat perbedaan rata-rata abnormal return pada waktu sebelum dan setelah pemilu presiden Indonesia tahun 2019

$\mathrm{H}_{4}$ : terdapat perbedaan rata-rata trading volume activity pada waktu sebelum dan setelah pemilu presiden indoensia tahun 2019

\section{METODE PENELITIAN}

\section{Jenis Penelitian}

Penelitian ini adalah penelitian kuantitatif yaitu menekankan analisis pada data-data angka yang diolah dengan menggunakan metode stastistik. Jenis penelitian ini adalah event study (studi peristiwa) yaitu studi yang mempelajari reaksi pasar terhadap suatu peristiwa yang informasinya diinformasikan sebagai pengumunan. ${ }^{9}$

\section{Sumber Data}

Sumber data pada penelitian ini menggunakan data yang dipublikasikan di website Bursa Efek Indonesia www.idx.co.id. Peneliti memilih sumber data di Bursa Efek Indonesia karena Bursa Efek Indoensia merupakan pusat informasi perusahaan yang go public di Indoensia sehingga menyediakan berbagai sumber data yang diperlukan.

\section{Populasi dan Sampel Penelitian}

Populasi yang digunakan dalam penelitian ini adalah perusahaanperusahaan yang terdaftar sebagai anggota LQ45 di Bursa Efek Indonesia (BEI). Pengambilan sampel penelitian ini menggunakan teknik purposive sampling yaitu penarikan sampel yang dilakukan secara sengaja berdasarkan pertimbangan yang telah ditetapkan. Kriteria yang ditetapkan oleh peneliti adalah sebagai berikut:

1. Tercatat sebagai anggota indeks LQ45 selama periode penelitian

${ }^{9}$ JogiyantoHartono. 2010. Teori Portofolio dan Analisis Investasi dan Instrumen Keuangan Pasar Modal. cetakan ke-7. Jogjakarta:BPFE, Hal 555 


\section{Aktif ditransaksikan selama periode penelitian}

Berdasarkan kriteria diatas maka sampel penelitian yang peroleh sebanyak 45 perusahaan yang menjadi anggota LQ45.

\section{Periode Penelitian}

Periode penelitian yang dilakukan untuk meneliti peristiwa pemilu presiden 2019 ini adalah selama lima hari bursa sebelum pemilu dan lima hari bursa setelah pemilu. Alasan pengambilan waktu tersebut karena di sekitar peristiwa tersebut dianggap merupakan waktu yang rawan bagi investor untuk melakukan kegiatan perdagangan di pasar modal selain itu event window yang lebih panjang akan lebih menyulitkan peneliti karena dikhawatirkan kejadian yang diteliti akan tercampur dengan kejadian yang lain sehingga kejadian yang diteliti menjadi bias.

\section{Teknik Analisis Data}

\section{Uji Normalitas}

Uji normalitas bertujuan untuk menguji variabel-variabel penelitian dalam model regresi memiliki residual yang terdistribusi normal. Pengujian ini untuk mengetahui apakah data dapat terdistribusi normal atau tidak dengan menggunakan uji Kolmogorof Smirnov Test. Dasar pengambilan keputusan adalah apabila nilai probabilitas signifikannya diatas tingkat kepercayaan atau signifikansi 5\% maka, data terditribusi normal, begitu pula sebaliknya jika nilai probabilitas dibawah tingkat kepercayaan atau signifikansi 5\% maka, data tidak terdistribusi normal. ${ }^{10}$ Apabila hasil uji normalitas menunjukkan data tidak terdistribusi normal maka dapat menggunakan asumsi Central Limit Theorem, dengan syarat jumlah observasi cukup besar $(n>30)$ maka, asumsi normalitas dapat diabaikan.

\section{Uji Beda t-test}

Uji beda t-test dilakukan dengan membandingkan perbedaan antara dua nilai rata-rata dengan standar error dari perbedaan rata-rata dengan standar error dari perbedaan dua sampel. ${ }^{11}$ Penentuan uji beda ditentukan oleh uji normalitas data apabila data terdistribusi dengan normal maka, menggunakan statistik parametrik paired sample test namun apabila data tidak statistik nonparametrik wilcoxom signed rank test.

\footnotetext{
${ }^{10}$ Ghozali, Imam. 2011. Aplikasi Analisis Multivariant dengan Program IBM SPSS 19. Semarang: Bidang Penerbit Universitas Diponegoro, Hal 160

${ }^{11}$ Ibid, hal 64
} 
PEMBAHASAN DAN HASIL

\section{AbnormalReturn}

\section{Analisis Statistik Deskriptif}

Tabel 1 Statistik Deskriptif Rata-rata Abnormal return Saham Selama Periode Penelitian

\begin{tabular}{|l|l|l|}
\hline \multicolumn{1}{|c|}{ Periode } & \multicolumn{1}{|c|}{ Mean } & \multicolumn{1}{c|}{ Standar Deviasi } \\
\hline Sebelum & -0.000006600 & 0.3158945369 \\
\hline Sesudah & -0.001282505 & 0,4408519628 \\
\hline
\end{tabular}

Sumber: Data Sekunder diolah

Tabel 1 menunjukkan mean rata-rata abnormal return bersifat negatif pada waktu sebelum dan sesudah pemilu yaitu sebesar -0.000006600 dan -0.001282505 hal ini menunjukkan adanya penurunan return yang diterima oleh investor setelah adanya pemilihan umum presiden April 2019 dengan Standar Deviasi sebelum pemilu sebesar 0.3158945369 dan sesudah pemilu sebesar 0,4408519628.

Tabel 2 Rata-rata Abnormal Return Saham Secara Harian Selama Periode Penelitian

\begin{tabular}{|c|c|c|}
\hline Tanggal & Periode Penelitian & Rata-Rata Abnormal Return \\
\hline 10 April 2019 & $\mathrm{t}-5$ & 0.425959990 \\
\hline 11 April 2019 & $\mathrm{t}-4$ & 0.099587377 \\
\hline 12 April 2019 & $\mathrm{t}-3$ & -0.126467686 \\
\hline 15 April 2019 & $\mathrm{t}-2$ & -0.436366743 \\
\hline 16 April 2019 & $\mathrm{t}-1$ & 0.037254062 \\
\hline 17 April 2019 & $\mathrm{t}-0$ & -0.043445912 \\
\hline 18 April 2019 & $\mathrm{t}+1$ & 0.037254062 \\
\hline 19 April 2019 & $\mathrm{t}+2$ & 0.661945101 \\
\hline 22 April 2019 & $\mathrm{t}+3$ & -0.726805454 \\
\hline 23 April 2019 & $\mathrm{t}+4$ & 0.026103110 \\
\hline 24 April 2019 & $\mathrm{t}+5$ & 0.0372546062 \\
\hline
\end{tabular}

Sumber: Data Sekunder diolah 


\section{Uji Normalitas}

Tabel 3Uji Normalitas Data Rata-rataAbnormal return Saham

\begin{tabular}{|l|l|c|c|c|}
\hline Variabel & Periode & $\begin{array}{c}\text { Test } \\
\text { Kolmogorov- } \\
\text { Smirnov }\end{array}$ & Sig & Keterangan \\
\hline $\begin{array}{l}\text { Abnormal } \\
\text { Return }\end{array}$ & Sebelum & 0.394 & 0.998 & Data Terdistribusi Normal \\
\cline { 2 - 5 } & Sesudah & 0.705 & 0.703 & Data Terdistribusi Normal \\
\hline
\end{tabular}

Sumber: Data Sekunder diolah

Tingkat signifikansi rata-rata abnormal return sebelum pemilu presiden Indonesia menunjukkan $0,998>0,05$ berarti data abnormal return sebelum pemilu presiden Indoensia terdistribusi normal. Sesudah pemilu presiden menunjukkan tingkat signifikansi rata-rata abnormal return sebesar 0,703 $>0,05$ berarti bahwa data terdistribusi normal.

Uji Paired T Test

Tabel 4Uji Paired T TestAbnormal Return Sebelum dan Setelah Peristiwa Pemilu

\begin{tabular}{|c|c|c|c|c|c|}
\hline Variabel & Correlation & Mean & $\begin{array}{c}\text { Paired } \\
\text { Samples Test } \\
\text { t Hitung }\end{array}$ & $\begin{array}{c}\text { t } \\
\text { Tabel }\end{array}$ & Sig \\
\hline $\begin{array}{c}\text { Abnormal } \\
\text { Returnsebelum dan } \\
\text { AbnormalReturnsetelah }\end{array}$ & 0.263 & -0.007 & -0.031 & 2.132 & 0.976 \\
\hline
\end{tabular}

Sumber: Data Sekunder diolah

Pada tabel Uji Paired T Test menunjukkan nilai korelasi sebesar 0,263 berarti bahwa sebelum dan setelah pemilu memiliki hubungan yang sedikit kuat dan positif. Nilai t Hitung sebesar $-0.031<2,132$ bearti tidak signifikan.

Signifikan nilai probabilitas atau p value Uji Paired T Test sebesar 0,976 > 0,05 artinya bahwa tidak ada perbedaan yang sangat signifikan antara sebelum dan sesudah peristiwa pemilu presiden dengan mean bernilai negatif yaitu sebesar $-0,007$ yang berarti bahwa tidak terjadi kecenderungan peningkatan abnormal return setelah adanya pristiwa pemilu presiden.

\section{Trading Volume Activity}

\section{Analisis Statistik Deskriptif}

Tabel 5 Statistik Deskriptif Rata-rata Trading Volume Activity 
Selama Periode Penelitian

\begin{tabular}{|l|l|l|}
\hline \multicolumn{1}{|c|}{ Periode } & \multicolumn{1}{|c|}{ Mean } & \multicolumn{1}{c|}{ Standar Deviasi } \\
\hline Sebelum & -0.001538865 & 0.0005952093 \\
\hline Sesudah & -0.001967272 & 0,0013110574 \\
\hline
\end{tabular}

Sumber: Data Sekunder diolah

Berdasarkan hasil perhitungan statistik deskriptif pada tabel 1 menunjukkan adanya penurunan aktivitas volume perdagangan yang ditunjukkan dengan mean rata-rata trading volume activity bersifat negatif pada waktu sebelum dan sesudah pemilu yaitu sebesar -0.001538865 dan -0.001967272 dengan standar deviasi sebelum pemilu sebesar 0.0005952093 dan sesudah pemilu sebesar 0,0013110574 .

Tabel 6 Rata-rata Trading Volume Activity Secara Harian Selama Periode Penelitian

\begin{tabular}{|c|c|c|}
\hline Nomor & Periode Penelitian & Rata-Rata Trading Volume Activity \\
\hline 1 & $\mathrm{t}-5$ & 0.001365240 \\
\hline 2 & $\mathrm{t}-4$ & 0.000990728 \\
\hline 3 & $\mathrm{t}-3$ & 0.001088136 \\
\hline 4 & $\mathrm{t}-2$ & 0.001812083 \\
\hline 5 & $\mathrm{t}-1$ & 0.002438138 \\
\hline 6 & $\mathrm{t}-0$ & 0 \\
\hline 7 & $\mathrm{t}+1$ & 0.003647309 \\
\hline 8 & $\mathrm{t}+2$ & 0 \\
\hline 9 & $\mathrm{t}+3$ & 0.001822008 \\
\hline 10 & $\mathrm{t}+4$ & 0.002368147 \\
\hline 11 & $\mathrm{t}+5$ & 0.001998896 \\
\hline
\end{tabular}

Sumber: Data Sekunder diolah

\section{Uji Normalitas}

Tabel 7Uji Normalitas Data Rata-rataTrading Volume Activity

\begin{tabular}{|l|l|c|c|c|}
\hline Variabel & Periode & $\begin{array}{c}\text { Test } \\
\text { Kolmogorov- } \\
\text { Smirnov }\end{array}$ & Sig & Keterangan \\
\hline $\begin{array}{l}\text { Abnormal } \\
\text { Return }\end{array}$ & Sebelum & 0.480 & 0.975 & Data Terdistribusi Normal \\
\cline { 2 - 5 } & Sesudah & 0.572 & 0.899 & Data Terdistribusi Normal \\
\hline
\end{tabular}

Sumber: Data Sekunder diolah

1. Tingkat signifikansi rata-rata trading volume activity sebelum pemilu presiden Indonesia menunjukkan $0,975>0,05$ berarti data trading volume activity sebelum pemilu presiden Indoensia terdistribusi normal.

2. Tingkat rata-rata trading volume activitysetelah pemilu presiden menunjukkan tingkat signifikansi sebesar $0,899>0,05$ berarti bahwa data terdistribusi normal. 
Uji Paired T Test

Tabel 8Uji Paired T Test Trading Volume Activity
Sebelum dan Setelah Peristiwa Pemilu
\begin{tabular}{|c|c|c|c|c|c|}
\hline Variabel & Correlation & Mean & $\begin{array}{c}\text { Paired } \\
\text { Samples Test } \\
\text { t Hitung }\end{array}$ & $\begin{array}{c}\text { t } \\
\text { Tabel }\end{array}$ & Sig \\
\hline $\begin{array}{c}\text { Trading Volume } \\
\text { Activitysebelum dan } \\
\text { AbnormalReturnsetelah }\end{array}$ & 0.317 & -0.000 & -0.763 & 2.132 & 0.488 \\
\hline
\end{tabular}

Sumber: Data Sekunder diolah

Hasil Uji Paired T Test trading volume activity menunjukkan nilai korelasi sebesar 0,317 berarti bahwa sebelum dan setelah pemilu memiliki hubungan yang sedikit kuat dan positif. Nilai t Hitung sebesar $-0.763<2,132$ artinya tidak signifikan.

Signifikan nilai probabilitas atau p value Uji Paired T Test trading volume activity sebesar $0,488>0,05$ artinya bahwa tidak ada perbedaan yang sangat signifikan antara sebelum dan sesudah peristiwa pemilu presiden dengan mean bernilai negatif yaitu sebesar $-0,000$ yang berarti bahwa tidak terjadi kecenderungan peningkatan abnormal return setelah adanya pristiwa pemilu presiden.

\section{Interpretasi Hasil}

Peristiwa pemilu presiden Indonesia tahun 2019 merupakan situasi politik yang bersifat makro yang diharapkan dapat membawa perubahan-perubahan yang lebih baik bagi kesejahteraan rakyat dari hasil kinerja presiden pada periode sebelumnya. Setiap ada pemilihan presiden selalu muncul isu-isu yang berkaitan dengan ekonomi, sosial dan lingkungan dan berbagai aspek lainnya. Sebuah informasi dianggap baik apabila direspon secara positif oleh pasar, hal itu ditunjukkan dengan adanya abnormal return diantara periode penelitian, namun apabila informasi dianggap kurang baik maka akan direspon secara negatif oleh pasar yang ditunjukkan dengan abnormal return yang bersifat negatif ${ }^{12}$ Respon pasar dapat diketahui dari dua hal diantaranya adalah abnormal return dan trading volume activity (TVA) disekitar event date. Perhitungan abnormal return menggunakan return realisasi dengan expected return sebagai dasar perhitungan. Return realisasi sangat penting karena sebagai dasar pengukuran kinerja perusahaan dan juga dasar dalam perhitungan expected return dimasa yang akan

${ }^{12}$ EduardusTandelilin. 2010. Portofolio dan Investasi, edisi 1, Yogyakarta: Kanisius, Hal 565 
datang. Penelitian ini merupakan penelitian event study dimana penelitian ini meneliti kandungan informasi dari suatu peristiwa yang memiliki sifat efisien stengah kuat. Pengujian informasi hanya menguji reaksi dari pasar tidak menguji seberapa cepat pasar bereaksi dalam merespon suatu informasi.

Abnormal return merupakan selisih antara expected return dengan relized return, expected return adalah return yang diharapkan oleh investor. Dasar perhitungan expected return dapat menggunakan indeks pasar pada saat penutupan dan realized return. Realized return merupakan return yang diperoleh oleh investor, realized return selain digunakan sebagai acuan untuk menentukan expected return juga digunakan sebagai indikator untuk mengukur kinerja perusahaan. Penentuan expected return menggunakan market-adjusted model dasar pengukuran expected return menggunakan Indeks LQ45 pada hari penutupan.

Hasil pengujian uji beda menggunakan uji paired t testrata-rata abnormal return menunjukkan bahwa $\mathrm{H} 1$ menyatakan bahwa tidak terdapat perbedaan yang signifikan dengan adanya peristiwa pemilu presiden Indonesia, pada tabel 2 menunjukkan pergerakkan rata-rata abnormal return bergerak secara fluktuatif dan cenderung negatif. Setelah pemilu abnormal return muncul pada $t+1$, abnormal return tertinggi terjadi pada $\mathrm{t}+2$, munculnya kembali abnormal return pada $t+5$ kemungkinan terjadi karena pasar masih menunggu kepastian mengenai hasil real qount dari pemilu presiden. Menurut tandelili jika pasar meragukan kebenaran suatu informasi maka akan terjadi respon yang terlambat dari pelaku pasar hingga mendapat kepastian mengenai informasi tersebut. Muncul abnormal return pada $\mathrm{t}+5$ ini mengidentifikasi bahwa masih ada pelaku pasar yang terlambat dalam menanggapi informasi yang ada. ${ }^{13}$

Trading volume activity(TVA) merupakan perbandingan antara saham yang diperdagangkan pada saat itu dengan saham yang beredar pada periode tersebut. Kinerja suatu saham dapat diukur dengan volume perdagangannya, semakin sering suatu saham diperdagangkan menandakan bahwa saham tersebut aktif dan diminati oleh investor. Trading volume activity juga dapat digunakan untuk melihat kandungan informasi dari suatu peristiwa dengan melihat rasio jumlah saham yang beredar.

Hasil pengujian uji beda rata-rata dengan uji paired t test tading volume activity $\mathrm{H}_{2}$ (Hipotesis 2) menunjukkan bahwa tidak terdapat perbedaan rata-rata trading volume cativity yang signifikan dengan adanya peristiwa pemilu presiden Indonesia, berdasarkan informasi dari tabel 6 menunnjukan bahwa pergerakan rata-rata TVA secara harian cenderung naik pada saat sebelum pemilihan presiden dan fluktuatif pada saat setelah pemilu presiden namun masih bersifat positif, ratarata TVA tertinggi terjadi pada $\mathrm{t}+1$. Namun hal ini tidak sejalan dengan rata-rata abnormal return harian, rata-rata abnormal return harian tertinggi pada $\mathrm{t}+2$ sedangkan rata-rata trading volume activity tertinggi ini diikuiti oleh abnormal return meskipun rata-rata hasil abnormal return bersifat negatif.

${ }^{13}$ Ibid, Hal 565 
Penentu pergerakan IHSG disebabkan oleh banyak faktor diantaranya adalah faktor ekonomi. Faktor ekonomi dapat dipengaruhi oleh beberapa hal yaitu tingkat suku bunga dan inflasi. Tingkat inflasi pada bulan April sebesar 2,83\%, tingkat inflasi pada bulan April lebih tinggi dari bulan-bulan sebelumnya yaitu pada bulan Maret sebesar 2, 48\%, dan bulan Februari sebsar 2,57\%. Peningkatan tingkat inflasi ini merugikan bagi perusahaan karena biaya operasional dan biaya bahan baku akan naik, maka laba bersih yang diperoleh oleh emiten akan menurun. Jika hal ini terjadi pada semua perusahaan yang tercatat di BEI maka akan menurunkan harga saham. Selain faktor ekonomi faktor non ekonomi juga berpengaruh terhadap IHSG. Adanya pergerakan secara fluktuatif IHSG disekitar periode pengamatan pada waktu sebelum dan sesudah pemilu presiden Indonesia dapat mengidentifikasi bahwa para pelaku pasar sulit untuk merespon baik peristiwa pemilu presiden sehingga relatif mengalami penaikan dan penurunan yang kurang stabil hal ini juga berdampak pada kondisi politik di Indonesia yang kurang kondusif.

\section{KESIMPULAN DAN SARAN}

\section{Kesimpulan}

Hasil uji beda rata-rata abnormal return sebelum pemilu presiden dengan rata-rata abnormal return setelah pemilu presiden menunjukkan dengan adanya peristiwa pemilu presiden Indonesia tahun 2019 tidak terdapat perbedaan yang signifikan pada abnormal return setelah pemilu presiden Indoensia tahun 2019.

Hasil uji beda rata-rata trading volume activity sebelum pemilu presiden dengan trading volume activity setelah pemilu presiden menunjukkan dengan adanya peristiwa pemilu presiden Indoensia tahun 2019 tidak terdapat perbedaan yang signifikan pada trading volume activity setelah pemilu presiden Indoensia tahun 2019.

Berdasarkan uji statistik yang telah dilakukan pada rata-rata abnormal return pada saat sebelum pemilu presiden dengan rata-rata abnormal return setelah pemilu presiden menunjukkan terdapat peningkatan mean pada rata-rata abnormal retun yang berarti terdapat perbedaan antara sebelum dan setelah pemilu presiden.

Berdasarkan uji statistik yang telah dilakukan pada rata-rata trading volume activity pada saat sebelum pemilu presiden dengan rata-rata trading volume activity setelah pemilu presiden menunjukkan terdapat peningkatan mean pada rata-rata trading volume activity yang berarti terdapat perbedaan antara sebelum dan setelah pemilu presiden.

\section{Saran:}

Pada penelitian yang selanjutnya yang memiliki fokus yang sama mungkin bisa menambah sampel penelitian dengan menggunakan seluruh perusahaan yang tercatat di Bursa Efek Indonesia sebagai sampel penelitian. Penambahan sampel penelitian ini diharapkan menghasilkan penelitian yang lebih akurat. 
Investor harus memahami setiap peristiwa yang berdampak secara makro karena tidak hanya faktor ekonomi saja yang dapat mempengaruhi harga saham dipasar tetapi faktor non ekonomi pun bisa mempengaruhi pergerakan harga saham. Investor sebaiknya dapat mengamati pergerakan harga saham disekitar peristiwa agar dapat menjadi acuan dalam melakukan trading dan mengambil keputusan yang tepat.

Perusahaan dapat mengantisipasi kebijakan-kebijakan dan regulasi-regulasi dari pemerintah yang baru. Kondisi politik dapat mempengaruhi arah kebijakan dan kondisi ekonomi sehingga perusahaan perlu mengantisipasi agar tetap stabil dan memiliki daya saing dengan perusahaan lain.

\section{Daftar Pustaka}

Abdul Halim, 2005, “Analisis Investasi”, Salemba Empat, Jakarta, hal.4.

Ghozali, Imam. 2011. Aplikasi Analisis Multivariant dengan Program IBM SPSS 19. Semarang: Bidang Penerbit Universitas Diponegoro.

Hadi, Nor. 2013. Pasar Modal: Acuan Teoritis dan Praktis Investasi dan Instrumen Keuangan Pasar Modal. Edisi Pertama, Yogyakarta: Graha Ilmu.

Hartono, jogiyanto. 2010. Teori Portofolio dan Analisis Investasi dan Instrumen Keuangan Pasar Modal. cetakan ke-7. Jogjakarta:BPFE.

Sugiyono. 2011. Metode Penelitian Kuantitatif Kualitatif dan $R \& D$, cetakan ke13. Bandung: Alfabeta.

Tandelilin, Eduardus. 2010. Portofolio dan Investasi, edisi 1, Yogyakarta: Kanisius.

Anggraini, Diany Ayunda. 2012. Analisis Pengaruh Kondisi Politik Dalam Negeri Terhadap Abnormal Return Indeks LQ45. Jurnal Akuntansi Universitas Indoensia.

Sri, dkk 2009. Analisis Reaksi Investor Terhadap Pengumuman Right Issue di Bursa Efek Jakarta. Jurnal Wacana Vol 12 No. 4

www.idx.ac.id

www.bi.go.id

www.yahoofinance.com 